\title{
Post-democracy and institutionalized austerity in France: budgetary politics during François Hollande's presidency
}

\author{
Andrew Glencross ${ }^{1}$
}

Published online: 6 February 2018

(C) The Author(s) 2018. This article is an open access publication

\begin{abstract}
This paper applies the concept of post-democracy coined by Crouch to shed light on the emerging political dynamics of macroeconomic policy coordination in the Eurozone as they applied to France during Hollande's presidency. Firstly, the paper explains the nature of EMU reform, characterized here as post-democratic by institutional design, before analysing its impact on France's budgetary politics. Finally, the French case involving Hollande's balancing act between supranational rules and domestic spending preferences is used as a way to reflect on the stability of this post-democratic arrangement for rescuing the Euro. The 2017 presidential election pitting Macron against Le Pen showed that post-democracy by design is sustainable only if the supply side of politics remains supportive of EMU-a condition undermined by the institutionalization of austerity, at least in France.
\end{abstract}

Keywords Post-democracy · EMU reform · French fiscal policy · Europeanization · Budgetary politics · Hollande

\section{Introduction}

This paper uses the concept of post-democracy coined by Crouch $(2000,2011)$ to shed light on the emerging political dynamics of macroeconomic policy coordination in the Eurozone as they applied to France during the presidency of François Hollande (2012-2017). In so doing, the aim is to connect the budgetary politics of Hollande's quinquennat with the institutionalization of austerity as the EU's solution to the Eurozone crisis under the impetus of German policy-makers (Blyth 2013; Bulmer and Paterson 2013). Post-democracy is a particularly useful lens through which to view the consequences of reforms to Economic and Monetary

Andrew Glencross

a.glencross@aston.ac.uk

1 Department of Politics and International Relations, Aston University, Birmingham, UK 
Union (EMU) that were beholden to an economic narrative identifying public debt as the cause of the crisis (Baldwin et al. 2015). This is because post-democracy is an explanatory tool for understanding both the causes and consequences of dwindling electoral opportunities for changing socio-economic models in countries such as France (Mouffe 2005).

France's relationship to the Europeanization of budgetary politics following the launch of the Euro is a complex and sometimes contradictory one. French policymakers had long considered the single currency as a mechanism for gaining more autonomy over monetary policy (Marsh 2009) and a means to strengthen domestic efforts at fiscal consolidation (Bezes 2006), while at times rejecting binding fiscal rules when electorally inconvenient (Howarth 2007). The overhaul of EMU in the wake of the sovereign debt crisis that began in 2010 was beholden to an economic narrative that identified public debt as the cause of the crisis (Baldwin et al. 2015). Hence, the reforms reducing fiscal autonomy (Glencross 2014) exacerbated the French tension between promoting integration in economic governance and accepting legal constraints on spending decisions; friction in the Franco-German axis reflected the same problem of whether to emphasize policy coordination or austerity (Schild 2013; Clift and Ryner 2014).

In this context, the first aim of the article is to explore the impact of the new EMU on France's budgetary politics by analysing compliance with the so-called Fiscal Compact of 2012 as well as the European Semester established by the "sixpack" and "two-pack" reforms of 2011 and 2013, respectively. What this analysis demonstrates is that Hollande struggled for 5 years, caught between demands for less austerity from within his Socialist camp and supranational procedures for enforcing the rules governing the Euro. Having early on failed to change the nature of the rules themselves that his predecessor had agreed with the German chancellor, he spent most of his years in office seeking to influence how the new EMU rules would be applied. An administration elected ostensibly to advance an anti-austerity project across Europe became engaged in a constant back-and-forth negotiation to avoid sanctions as a result of an excessive deficit procedure (EDP).

Hollande's predicament illustrates a peculiar feature of the new EMU system, namely that it has engendered post-democracy by institutional design. Traditionally, post-democracy is considered a reflection of the hollowing-out of party politics (Mair 2013), in that changes in the composition of parties - notably the shift away from working class representation among social democratic parties (Heath 2015) greatly reduced the policy distance between centre-right and centre-left. A knock-on consequence of these "supply-side changes" in what politics offers is thus the stymying of opportunities for bottom-up policy change via electoral mobilization. In the British context for which Crouch first devised the term post-democracy, this policy convergence is exemplified by the economic policies pursued by Labour and Conservatives since the 1990s. Labour's embrace-under the leadership of Tony Blair-of the market economy and its neoliberal corollary, competitiveness via flexible labour markets, other forms of deregulation, and lower taxation, is symbolic of the dwindling ideological cleavage in British politics prior to Brexit (Bevir 2000). The politics surrounding the adoption of austerity measures in the UK since 2010 further illustrates the supply-side basis of this kind of post-democracy, especially in 
the field of macroeconomic policy. For despite much criticism of the UK's growth model in the wake of the financial crisis, the government pursued austerity for the sake of preserving the pre-crisis neoliberal system (Berry 2016). This task was made all the easier as the main opposition, Ed Miliband's Labour Party, was so desperate to regain economic credibility among voters that it fought the 2015 general election on a pledge to pursue austerity at a slightly slower pace (Bale 2015). In this manner, budgetary politics are constrained because of the supply of policies chosen by the two main parties and are not a product of EU rules. By contrast, this article argues that under the new EMU rules post-democracy is a product of the supranational decision to institutionalize austerity, enforced by budgetary oversight exercised by the European Commission, thereby removing alternative policy options at the domestic level.

Consequently, the second objective of the article is to analyse the stability of this post-democratic arrangement for rescuing the Euro and which relies on a "ruling by numbers" logic (Schmidt 2015). Post-democracy is a potent way to explain the appeal of anti-system parties in the West precisely because they can present themselves as offering the only genuine alternative to cartel parties of both the centre-left and the centre-right that have fused with the state apparatus and supposedly ignore popular concerns over the economy and society (Richards and Smith 2015). France is an ideal test case for understanding the impact of Eurozone post-democracy not just because of the established presence of the populist Front National, but also because it has a record of ignoring EMU fiscal rules (Clift 2006) and of using its influence to avoid the accompanying sanctions (Heipertz and Verdun 2010).

Ultimately, the article demonstrates that while EMU reform has institutionalized post-democracy, at least when it comes to budgetary politics, this is far from being a stable arrangement. France's experience with attempting to comply with its EDP, which involved persuading the European Commission that the government was serious about tackling the deficit, reveals the impossibility of depoliticizing budgetary politics via legal constraints on spending and reliance on expertise-led policy recommendations. Indeed, the 2017 presidential election amply highlighted the potential limits of post-democratic European integration. The second-round runoff between Emmanuel Macron and Marine Le Pen pitted a pro-EU candidate promising Eurozone reform against an anti-Euro one. What this suggests is that post-democracy by design is only sustainable if the supply side of politics remains supportive of EMU or integration more generally - a condition undermined by the institutionalization of austerity, at least in France.

\section{The reformed Eurozone and post-democracy}

Both the intellectual and the popular debate surrounding EMU reform have focused on austerity and its discontents (Blyth 2013; Varoufakis 2017). This is unsurprising as the imposition of austerity in return for bailouts in Greece, Portugal, Cyprus, and Ireland provided a common banner under which diverse political constituencies can be mobilized. Such appeals rely, in various doses, on sovereignty, nationalism, and 
Keynesianism in order to protest against budget cuts and present an alternative to spending cuts. The true novelty of the EU response lies less in the conditionality imposed in return for bailouts, and more in the altered legal-political architecture of the Eurozone, which notably includes the revised Stability and Growth Pact, including the provisions of the "European Semester", and the so-called Fiscal Compact. It is these pre-emptive measures for countries not in need of a bailout, such as France during the Hollande years, that have fundamentally Europeanized budgetary politics in a post-democratic institutional setting.

Since it was national governments and their taxpayers that would have to guarantee bailout funds for countries frozen out of financial markets, it was inevitable that the Eurozone's heads of state and government would play the decisive role in devising the terms of the bailouts (Puetter 2012). The result was an unprecedented form of top-down economic management in which the EU became directly implicated in deciding national tax and spending policies in countries receiving a bailout, an emergency exercise justified on the basis of an exogenous shock. The legitimacy of the mechanism by which these changes were wrought, in response to a perceived emergency, is itself open to question (White 2015; Crouch 2016). But more interesting still from the perspective of post-democracy are the implications of the radical reconfiguration of EMU, i.e. the creation of lasting structures restricting member states' macroeconomic discretion-regardless of whether they are in receipt of a bailout or not. It is within this new policy space that the post-democratic features of budgetary politics and its consequences have become apparent.

Perhaps the most striking element of EMU reform came in the shape of the intergovernmental Treaty on Stability, Coordination, and Governance in the Economic and Monetary Union, which entered into force on 1 January 2013. This was a bold attempt to set in stone fiscal responsibility so as to reassure the markets, as well as the ECB which held the key to preventing a crisis of confidence in EMU countries' bonds by acting as lender of last resort to sovereigns (Woodruff 2016). The terms of the treaty were inspired by Germany's 2009 Schuldenbremse (debt brake) legislation designed to make it constitutionally impossible to run up government debt in the long term (Glencross 2014). Via an international treaty-not an EU legal text - the signatories agreed to introduce binding national commitments to run balanced budgets, which means no annual deficit above $0.5 \%$ of GDP is permissible in the medium term. The Commission defines the period in question as 3 years, meaning that even though the deficit figure is calculated on the basis of a structural and not a nominal target it leaves little room for significant demandmanagement policies as these would have to be conducted in a short space of time and under scrutiny of supranational actors. What makes the treaty more restrictive than the original SGP is that it obliges countries to enshrine in primary law the obligation to pay back debt, if it reaches a ratio of more than $60 \%$ of GDP, at an average rate of one twentieth per year.

The incentive structure behind what popularly became known as the Fiscal Compact was linked to the contemporaneous establishment of a permanent bailout fund for sovereigns facing borrowing difficulties, the European Stability Mechanism (ESM). Funds from the ESM are only available to member states that adopt the 
Fiscal Compact's debt brake, a condition sought by the ECB to avoid generating "moral hazard", i.e. preventing states from using bailout funds to keep spending beyond their means (ibid.). Both the ESM and the associated Fiscal Compact were established in the face of a perceived emergency where the need to reassure market actors was paramount and even exploited strategically to some extent by actors such as the ECB to push their preferred policies of fiscal discipline accompanied by structural reforms (Woodruff 2016).

This resort to emergency politics-government by exception-in the wake of a financial crisis is not in itself a new phenomenon in European governance (White 2015). Its novelty, from the perspective of post-democracy, resides in the fact that these emergency measures are explicitly designed to have long-lasting policy effects by significantly reducing the scope for national discretion over spending decisions regardless of electoral preferences. Revisions to EMU are in effect destined to remain on the statute book indefinitely because of the political impracticality of overturning the EU and international legal basis of these changes. The result is an institutionalization of austerity for years to come in the Eurozone by removing the possibility of implementing demand-management policies at the national level, even though the political economy of the Eurozone combines export-led and demand-led growth models that react very differently to changes in the economic cycle (Hall 2012). German Chancellor Angela Merkel expressed the intention more bluntly by explaining that a new treaty was needed so that "the debt brakes will be binding and valid forever...never will you be able to change them through a parliamentary majority" (Guardian 2012). In other words, should the consensus over the narrative of how to respond to the crisis shift, there are legal constraints on satisfying demands - whether electoral or on the basis of expertise - for alternative budgetary policies.

The logic of constraining national budgetary autonomy resembles in fact the broader effects of European integration through law in which competences lost at the member state level (e.g. state intervention to protect jobs) have not been replicated for the EU as a whole. That is, EU treaties and secondary legislation associated with the construction of a pan-European single market have not been accompanied by the establishment of equally robust market-correcting competences. The result, in the words of Scharpf, is the "systematic weaken[ing of] established socio-economic regimes at the national level" (Scharpf 2010: 243), thereby increasing the inequalities born of ever more competitive market relations. However, the uneven balance between the EU's deregulative and re-regulative outputs was by no means the explicit and universal intention of EU policy-makers. Rather, it was a reflection of the incremental accretion of EU competences and the lag-time between market deregulation and political spillovers sufficient to motivate re-regulation (Schimmelfennig 2014).

Yet in the case of the Fiscal Compact, there is no conceit that the bar on Keynesian-style policy solutions is merely a temporary fix until the tools for EUlevel intervention are established. National parliaments that have ratified the treaty have permanently reduced-providing the rules can be enforced, which is debatable (Kelemen and Teo 2014) — the space for policy disagreement between parties over public spending decisions. In this way, a key feature of post-democracy, 
the narrowing of policy options the electorate can choose from, is the product of the institutionalization of more stringent budgetary rules across the Eurozone.

The same trend is equally in evidence in the creation of the European Semester for monitoring national budgetary proposals and enhancing macroeconomic policy coordination. Proposed in September 2010, the European Semester became law in November 2011 as part of the so-called six pack of emergency measures to stabilize the Euro that also empowered the Commission to propose corrective policies in the event that a country misses the medium-term targets of the SGP. Overall, the five regulations and one directive constituting the "six pack" enhanced supranational actors' ability to trigger an EDP and to impose sanctions for failing to comply with these terms. This less politicized and ad hoc approach to enforcement was complemented by the 2013 "two pack", which introduced enhance surveillance powers enabling the Commission to issue recommendations independently of the Council, which in turn could lead to sanctions if these are not respected.

The year-long cycle at the heart of the European Semester is intended to coordinate macroeconomic policy by assessing a country's economic performance as part of a Macroeconomic Imbalance Procedure (MIP). This mechanism provides a way to scrutinize the implementation of country-specific recommendations (CSRs) addressed to individual member states by the Council with input from the Commission every summer. The MIP carries the potential for financial sanctions ( $0.1 \%$ of GDP for Eurozone countries only) for failure to take action when the Commission identifies an excessive imbalance and requests a corrective action plan. In parallel with the MIP, the European Semester also empowers the Commission to examine member states' draft budgets (which must be prepared by 15 October) and proposals for various economic reforms stemming from stability programmes issued in April (Dunlop and Radaelli 2016). Throughout the process, there is a special focus on government expenditure and whether it grows faster than GDP, a consideration not included in the original SGP. In addition to fiscal consolidation, CSRs cover tax reforms, labour costs, and other measures associated with competitiveness. Such recommendations follow a rationale of impartial expertise associated with delegation of policy powers to non-majoritarian institutions (Majone 2001) as well as a policy learning approach that promotes change on the basis of efficiency and objective evidence, not electoral considerations (Dunlop and Radaelli 2016).

Part of the EMU reforms also include the need for each member state to create an independent fiscal council that reports on the state of public finances in order to use expert analysis to counterbalance politicians' self-serving use of spending figures. These examples demonstrate that the European Semester is premised on a postdemocratic logic condition of taking the sting out of the political debate over major macroeconomic policy choices by appealing - if not, at times, outsourcing decisions - to independent expertise. In particular, the use of the supposedly neutral and objective language of "competitiveness" to justify the CSRs is not trivial: it points to a technocratic realm of managing the economy that lies beyond the proper sphere of political competition. It is precisely this kind of competence delegation that Crouch (2016) holds responsible for the personalization and indeed trivialization of politics under post-democracy. 
In its first years, the European Semester has been considered a weak mechanism in that member states have a poor record in implementing CSRs (Darvas and Leandro 2015). Nevertheless, financial penalties could be imposed in theory for such failures when associated with excessive deficit procedures (EDP) or excessive imbalance procedures, one or both of which applied during the course of Hollande's 5-year presidential term of office. As with the establishment of the Euro itself, France accepted the European Semester as a potential stepping stone towards greater EU-wide economic governance where French interests could be asserted. The functioning in practice of this new institutional design, however, meant that Hollande always had to reckon with increased supranational scrutiny of French budgetary decisions.

\section{Adapting to institutionalized austerity in the Eurozone: the presidency of François Hollande}

The measures described above have a Brave New World feel to them. That is, the new framework for EMU revolves around getting member states such as France to like implementing reforms they have hitherto been so hesitant to enact, much as the inhabitants of Huxley's dystopia are programmed to be contented with their lot. Whereas it might have been assumed that the scale of the financial crisis would engender a transformation of Western political economy, as in past crises such as the Great Depression, the striking feature since 2008 is the "strange non-death of neo-liberalism" (Crouch 2011). The institutionalization of austerity in the Eurozone has proved particularly challenging for social democratic parties such as Hollande's Parti Socialiste as it makes electoral promises that the EU will eventually deliver greater social rights increasingly ring hollow. Indeed, EU bailouts in peripheral Eurozone countries engendered novel party dynamics as explicitly anti-austerity left parties sought to mobilize voters around an alternative vision of integration (Ramiro 2016).

Conscious of the risk of being outflanked on the left Hollande's approach at first was to seek EU-wide change by contesting the turn towards Brussels-mandated austerity established by the Merkozy tandem (Schild 2013). Campaigning for the presidency in 2012, he promised to persuade the European Commission to fund jobcreating measures to counteract the loss of privately funded investment caused by the fragility of the European banking sector (Clift 2013). This proposed "growth pact" was part of a more ambitious pledge to renegotiate the as yet unratified Fiscal Compact by including specific provisions for deficit spending in recessions and creating Eurobonds to reduce government borrowing costs or any sovereign credit crunch. In using this rhetoric, Hollande was aware of France's precarious fiscal position bequeathed by Sarkozy, who deliberately postponed budgetary consolidation until after the 2012 electoral cycle (Bezes and Le Lidec 2015).

Soon after his election, the new French president rather publicly lost the confrontation with Germany over the establishment of Eurobonds and less stringent rules for the Fiscal Compact at his first European Council summit in June 2012 (Clift and Ryner 2014). Instead of seeking to shift the Eurozone away from 
austerity, the French government became preoccupied by how to manage the ongoing EDP overseen by the Commission. In this way, the institutionalization of post-democracy shifted the domain of political contestation for the Hollande presidency away from a diplomatic debate over changing EMU rules to an ongoing negotiation regarding how they would be applied in practice, bearing in mind domestic constraints over highly sensitive cuts and policy reforms.

Under the terms of the Stability Programme submitted to the Commission in April 2011, France was supposed to return to within the $3 \%$ headline deficit limit of the SGP by 2013, representing an extension from the original date of 2012. In September 2012, Hollande's government introduced the first loi de programmation des finances publiques to comply with the Fiscal Compact, which promised to stick to the 2013 EDP target while reaching the $0.5 \%$ structural deficit by 2015 and eventually $0 \%$ in 2017 . This plan rested on $€ 30$ billion of combined spending cuts and extra revenue as set out in the budget for 2013. However, the Commission's Spring Forecast of 2013 gave the lie to the notion that France would meet the SGP criteria that year (European Commission 2013). That document noted the deterioration in public finances compared with the previous estimates and remarked pointedly that funding of Hollande's flagship pacte de compétitivité initiative, designed to reduce certain employment taxes, was yet to be specified in detail.

The Commission's prognoses meant that France would need to revise its fiscal stance significantly in order to convince Brussels that it was serious about complying with the SGP in order to avoid sanctions under the EDP. Discursively, the French government's tactic involved highlighting the scale of adjustment already undertaken - an unprecedented 4.6\% of GDP between 2010 and 2013alongside the argument that immediate measures to reach the 3\% target in 2013 would tip the country into recession. The official line, as set out in the 2013 Stability Programme released in April 2013, was that these "efforts should be acknowledged and that the return to a nominal deficit of less than $3 \%$ of GDP should be deferred until 2014" (French Government 2013). The strategy paid off as on 29 May 2013 the Commission recommended extending the EDP deadline by another 2 years, a decision ratified by ECOFIN in June that year. The Council concluded that "unexpected adverse economic events" were the reason why France had not been able to meet its expected fiscal objectives and set out a precise schedule for future budget deficits and overall improvement in the structural balance (i.e. the difference between expenditure and revenues taking account of the economic cycle) totalling nearly 3\% of GDP (see Table 1). It also gave a deadline of 1 October 2013 for taking effective action, presented in the form of a document called the Economic Partnership Programme (EPP), to ensure a correction of the excessive deficit by 2015.

France's EPP was given a lukewarm evaluation by the Commission, confirmed by the Council on 10 December, which noted that it provided "a set of fiscalstructural reforms that is partly adequate to support an effective and lasting correction of the excessive deficit" (Council of the European Union 2013). In essence, the budget forecasts for growth and spending were left unchanged for the year, as Hollande wanted to avoid further political controversy that might arise from changes in pensions, unemployment, or healthcare while still focused on what was 
Table 1 Fiscal consolidation targets specified in the 2013 EDP extension

\begin{tabular}{lccc}
\hline & $2013(\%)$ & $2014(\%)$ & $2015(\%)$ \\
\hline Headline deficit (\% of GDP) & -3.9 & -3.6 & -2.8 \\
Structural adjustment (\% of GDP) & 1.3 & 0.8 & 0.8 \\
\hline
\end{tabular}

rebranded as a "pacte de responsabilité". The Commission's assessment of the draft national budget's projections for meeting the SGP target noted a marked discrepancy between French assumptions that 2015 would see a $2.8 \%$ deficit and its own figure of $3.7 \%$. Hence, the Council's opinion on the budget was, unsurprisingly, far from enthusiastic and specified that France needed to provide clarity on how proposed spending cuts would result in EDP compliance (ibid.) Consequently, 2014 was destined to be a crucial year in which France's budgetary politics, as scrutinized via the European Semester, would be dominated by the ongoing negotiation with an increasingly sceptical Commission.

The need for renewed reforms directly contradicted Hollande's 2013 message in the rentrée that a "fiscal pause" was in order for 2014 (Le Point 2013). To get back on track and avoid EDP sanctions, the government announced spending cuts of $€ 15$ billion and revenue-raising measures worth $€ 3$ billion in September's draft budget for 2014 (Table 2). Another sign that all was not going according to the agreed EDP timeline came when Hollande announced on 14 January that the pacte de responsabilité would be financed by a forthcoming slew of cuts totalling $€ 50$ billion up to 2017. Notwithstanding these promises, the Commission fired another warning shot by invoking Regulation 473/2013 which was part of the "two-pack" reform of the European Semester. This regulation allowed the Commission to issue an autonomous recommendation in March 2014 that France was heading towards noncompliance with its EDP and thus at risk of being sanctioned.

The Commission's document outlined the worsening of French public finances consequent to changes in tax legislation, including the government's climb-down over a controversial road haulage charge and modifications imposed by the Constitutional Court on planned income tax changes. In particular, Brussels indicated that more effort was needed to meet the Council's 2013 recommendation for a 1\% structural adjustment for 2013 and 2014, placing France at risk of non-

Table 2 French draft budgetary plans and deficit targets 2012-2017

\begin{tabular}{llllll}
\hline $\begin{array}{l}\text { Draft budget } \\
\text { (published Sept of } \\
\text { proceeding year) }\end{array}$ & $\begin{array}{l}\text { Spending } \\
\text { cuts }(€ \\
\text { billions })\end{array}$ & $\begin{array}{l}\text { Tax } \\
\text { increases } \\
(€ \text { billions })\end{array}$ & $\begin{array}{l}\text { Proposed } \\
\text { headline deficit } \\
(\% \text { GDP })\end{array}$ & $\begin{array}{l}\text { 2013 EDP } \\
\text { headline } \\
\text { deficit target }\end{array}$ & $\begin{array}{l}\text { 2015 revised } \\
\text { EDP headline } \\
\text { deficit target }\end{array}$ \\
\hline 2013 & 10 & 20 & 3 & 3.9 \\
2014 & 15 & 3 & 3.6 & 3.6 & \\
2015 & 21 & 0 & 4.4 & 2.8 & 4 \\
2016 & 16 & 0 & 3.3 & & 3.4 \\
2017 & 14 & 0 & 2.7 & & 2.8 \\
\hline
\end{tabular}


compliance and obliging it to respond to the recommendation for greater budgetary discipline. It also noted that the Stability Programme for 2014 projected a 3\% deficit for the following year, which was above the agreed 2.8\% EDP target. Such concerns fed into the critical CSR adopted by the Council in June 2014 that qualified French budget plans as "only partly in line" with the SGP and recommended curbing healthcare and pension spending as the only way to tackle the structural deficit.

The first half of 2014 proved in reality a budgetary phoney war as the expected growth figures and concomitant tax receipts were out of kilter with reality. In a press conference on 10 September, Michel Sapin, the minister of finance, admitted that the 2014 deficit would be $4.4 \%$ - a long way off what had originally been proposed in the draft budget and an increase in fact on the previous year's deficit. This revelation meant the EDP schedule for going under the 3\% SGP level was impossible to attain for 2015 and would be postponed until 2017. In the 2015, draft budget announced that same month, the government proposed cutting spending by $€ 21$ billion (the first tranche of the $€ 50$ billion promised in January 2014) so as to reach a $4.4 \%$ deficit, a full 1.6 percentage points more than what was expected from France by the EDP. Prime Minister Manuel Valls took pains to write to the Commission on 21 November after the budget had gained parliamentary approval, while also committing the government to more structural reforms in the shape of loosening rules for working on Sundays and other labour-market rigidities.

Valls' letter was a pre-emptive move as Brussels was due to report imminently on France's budget plans. A week later, and to no great surprise, the Commission announced in November 2014 that France's budget plans risked non-compliance with the EDP and invited the government to take measures to meet the terms of the SGP for 2015. But it postponed until March a final decision on SGP compliance, thereby creating a deadline for the climax of the showdown over whether to extend the EDP. Unlike in 2003/2004, financial penalties (up to $0.2 \%$ of GDP) were much more likely to be authorized as the six pack had introduced reverse qualified majority voting, meaning Hollande would need to caucus a blocking majority of Eurozone countries to avoid sanctions. Adding to the pressure on the French government was the simultaneous decision taken on 28 November by the Commission to declare that France was in a situation of excessive macroeconomic imbalances. The next step under the MIP, as had already been the case in previous years, was an in-depth country review published shortly after in December. Yet this time, since the imbalances were now considered excessive (see Table 3), there was the possibility that the IDR could lead to a Corrective Action Plan (CAP) and eventually financial sanctions of $0.1 \%$ of GDP if reforms were deemed inadequate. Looming over the French government for the next 6 months was the Commission's verdict, due in May 2015, on whether to recommend a CAP.

Hollande's gambit in this context was a plea for flexibility in the application of the SGP rules, all the while promising to continue structural reforms, so that the incremental effect of earlier measures would be felt and in the hope of a return to growth. This was the only option for avoiding extra fiscal measures that would cause further domestic political turmoil following the unprecedented disaster of the 2014 midterm regional elections (Kuhn 2014). Central to this strategy-as mentioned in the letter to the Commission in November-was the ongoing plan of Emmanuel 
Table 3 The French economy as assessed by the European semester's macroeconomic imbalances procedure

\begin{tabular}{|c|c|c|c|c|}
\hline Year & $\begin{array}{l}\text { Overall MIP } \\
\text { status }\end{array}$ & $\begin{array}{l}\text { In-depth } \\
\text { review } \\
\text { needed? }\end{array}$ & $\begin{array}{l}\text { Corrective } \\
\text { action plan } \\
\text { required? }\end{array}$ & $\begin{array}{l}\text { Additional information or measures required for } \\
\text { SGP? }\end{array}$ \\
\hline 2012 & Imbalances & Yes & Not applicable & No \\
\hline 2013 & Imbalances & Yes & Not applicable & $\begin{array}{l}\text { Economic partnership programme (by } 1 \mathrm{Oct} \text { ) - } \\
\text { deemed partly adequate }\end{array}$ \\
\hline 2014 & Imbalances & Yes & Not applicable & $\begin{array}{l}\text { Commission recommendation to meet structural } \\
\text { adjustment target (March) }\end{array}$ \\
\hline 2015 & $\begin{array}{l}\text { Excessive } \\
\text { imbalances }\end{array}$ & Yes & No & $\begin{array}{l}\text { Commission recommendation for effective } \\
\text { action on SGP and report on action taken by } \\
10 \text { June; 6-monthly reporting thereafter (Feb) }\end{array}$ \\
\hline 2016 & $\begin{array}{l}\text { Excessive } \\
\text { imbalances }\end{array}$ & Yes & No & No \\
\hline 2017 & $\begin{array}{l}\text { Excessive } \\
\text { imbalances }\end{array}$ & Yes & No & No \\
\hline
\end{tabular}

Macron, Minister of the Economy since August 2014, to shake up the labour market. Macron's appointment, coming on the back of the earlier Prime Ministerial change after the March elections, was in fact a statement of intent to continue on the path of structural adjustment favoured by Brussels as it came at the expense of Arnaud Montebourg who had pushed instead for a dirigiste industrial strategy to protect jobs.

In January 2015, the Commission signalled a more emollient line by issuing a communication that provided detailed guidance on how the SGP would be applied "while making the best use of the flexibility which exists within its rules" (European Commission 2015a). This very topic had been raised at the June 2014 European Council as part of Hollande's efforts for the EU to privilege growth and employment ahead of austerity. Beforehand, the French President met with socialist heads of state and government to coordinate this policy message and seek backing for a 1.2 trillion euro "New Deal" investment plan over the 5-year term of JeanClaude Juncker's incoming Commission. By doubling-down on his electoral promise to change the EU economic agenda, Hollande did help steer the Work Plan of the new commission, which in December 2014 included an "Investment Plan for Europe" designed to generate project funding of at least $€ 315$ billion over 3 years across the EU.

However, Hollande had few illusions about the extent to which a supposedly flexible interpretation of the SGP would ease pressure to push through politically sensitive reforms. The guidance from Brussels clearly stated that an extension of an EDP could occur only as quid pro quo for reforms that "(1) are major, (2) have verifiable long-term positive budgetary effects, including by raising potential sustainable growth, and (3) are implemented" (European Commission 2015a). Reform measures adopted by the government and/or the Parliament may also qualify ex ante if Member States have presented a dedicated structural reform plan with well-specified measures and credible timelines for their adoption and 
implementation. Thus, it was no coincidence that in the days before the Commission decided what to do about France's failure to meet its EDP targets Macron's labour law was forced through the National Assembly to overcome resistance in the ranks of the government's parliamentary majority. This was done by using the infamous 49-3 constitutional procedure associated with a governmental motion of confidence.

Ultimately, the Commission's recommendation for a 2-year postponement for getting under the $3 \%$ criterion, issued on 27 February 2015, offered France flexibility only in the sense of buying more time for austerity until the 2017 electoral cycle (European Commission 2015b). The pace of structural adjustmentconfirmed by the Council on 10 March-was increased, with targets of $0.2 \%$ for 2015 (by this time the deficit had been re-evaluated down to 4\%) followed by 1.2 and $1.3 \%$ for 2016 and 2017, respectively. The Council's decision came down to the conclusion that since the 2013 extension was granted "the available evidence does not allow to conclude on no effective action". As well as the new deficit targets (see Table 2), France was asked to undertake more measures for fiscal consolidation and provide updates to that effect by 10 June and every 6 months thereafter. Brussels expected to see the "implementation of comprehensive and ambitious structural reforms, in line with the Council Recommendations addressed to France in the context of the European Semester and in particular those related to the Macroeconomic Imbalance Procedure" (Council of the European Union 2015).

The summer of 2015 constituted the most significant pushback against the conjoined European Semester and EDP procedures during Hollande's quinquennat. In addition to the extension for SGP compliance, France also avoided being subject to a Corrective Action Plan under the MIP (as also occurred in the two subsequent years, see Table 3) and succeeded in having the wording of the Commission's annual recommendation in response to its national reform programme and concomitant stability programme changed. The original version expressed scepticism about France's planned fiscal consolidation and suggested there was a risk of non-compliance with the SGP (European Commission 2015b). Yet this modification was made possible because the French government outlined, in the report owed to the Council for 10 June, a further $€ 9$ billion of spending and revenue changes for 2015-2016 (in large part linked to low inflation and lower debt interest charges following ECB bond-buying) that brought the deficit numbers down by the required $0.2 \%$. These measures allowed the Council to recommend that the 2015 SGP target would be met (ibid.) at a time when Hollande had committed extra funds for a "security pact" following the Charlie Hebdo attacks. In other words, as with all the extra measures asked of France to comply with the SGP from 2012-2017 (see Table 3), even at this difficult time Hollande's government played ball via a combination of fiscal measures and structural reforms.

\section{France and the limits of post-democratic integration}

As demonstrated in the previous sections, radical reform of EMU has had a profound impact on budgetary politics by institutionalizing fiscal consolidation and structural reform even in the case of France, which had a record of skirting the 
budgetary rules of the SGP in an unrepentant fashion (Clift 2006). French presidents have approached the politics of retrenchment with an eye on electoral considerations (Bezes and Le Lidec 2015), while also supporting institutional momentum for developing tools of macroeconomic government at the Eurozone level even if their German counterparts have insisted on creating binding fiscal rules as a precondition. The French case is thus striking for revealing the constraints on budgetary flexibility that has been the political preference of successive presidents of different stripes. Post-democracy captures the complex bargaining over the application of the new EMU rules, which dominated Hollande's domestic socio-economic agenda, in that the concept both describes the narrowing of political choice and explains the resentment that develops in light of restricted opportunities for alternative socioeconomic policies. By considering Hollande's legacy-the first president of the Fifth Republic not to seek re-election-it is possible to show how the French example illustrates the inherent limits to post-democratic integration.

Hollande's presidency involved a constant balancing act with Brussels as he sought to maintain the pace of structural reforms and fiscal consolidation necessary to meet EMU rules, while managing the accompanying revolts on policies such as labour law reform or the aborted eco-tax. Walking this tightrope was made all the harder by the president's unwillingness to articulate to voters the scale of the fiscal challenge facing France (Gaffney 2015), especially during his initial months in office when responsibility could have been squarely placed on Sarkozy for concealing the size of the deficit (Bezes and Le Lidec 2015). This muted approach to discussing the parlous state of public finances was compounded by a reliance on optimistic growth forecasts-starting with those underpinning his 60 campaign pledges (Cole 2013) - that would reduce the need for painful retrenchment.

Initially, as a newly elected president, Hollande sought to politicize the institutional design of EMU knocked together in response to the financial crisis. His very public failure to achieve a shift from austerity to growth via public investment, and his equally public budgetary travails with the Commission analysed above, exposed the limitations on national democracy placed by membership of the Euro. The longer-term impact of Hollande's retrenchment policies is hard to judge because public spending remains difficult to reduce in real terms; in 2017 the Cour des comptes warned that to meet the EMU target of reducing the deficit by $0.5 \%$ would require unprecedented cuts. Breathing space could come in the form of higher than expected growth and lower borrowing costs associated with the ECB's unconventional monetary policy. Additionally, the ability of Brussels to demand further reforms is open to question especially as enforcement of the Fiscal Compact is debatable given it has no specific supranational sanctioning mechanism (Kelemen and Teo 2014).

Nevertheless, the article has demonstrated that Hollande's ability to gain an extension of the EDP in 2015 came at a price in order to satisfy the Commission; the ruling parliamentary majority was weakened, as exemplified by the need to force through Macron's labour law via Article 49-3. When faced by conflict between supranational rules and domestic budgetary preferences Hollande plumped for the former. This institutionalized post-democratic status quo reinforces the challenge facing centre-left parties such as the Parti Socialiste which find themselves in the 
unenviable situation of trying to reconcile their instinctive pro-European internationalism with acceptance of a regulatory polity that reduces the national capacity for welfare protection and spending (Dimitrakopoulos 2010).

As a result, in line with the expectation that post-democracy encourages the development of anti-system parties, during the Hollande years Marine Le Pen's Front National was able to supply a radical anti-EMU policy offering to an increasingly receptive electorate. In May 2014, Le Pen's party came first in the European Parliamentary elections with close to $30 \%$ of the vote, followed by further success in 2015 departmental and regional elections (Evans and Ivaldi 2017). The success of the twin rigours of the European Semester and the EDP in disciplining French public spending during Hollande's term of office thus came with a high political cost. Institutionalized austerity was the backdrop for the highly unusual presidential election in which a technocratically styled novice faced off against the anti-EMU far right. Emmanuel Macron's positioning as the pro-EU candidate defending French membership of the Euro was clear in the second round. His programme of seeking to adhere to the SGP rules as a prelude to a broader discussion-once again-of EMU reform is thus in keeping with the French tradition of promoting incremental steps towards economic governance for the Eurozone. However, the underlying story of the 2017 presidential election is that of a fragmented political space in which the economic dimension of political competition is increasingly polarized (Gougou and Persico 2017). The Hollande years thus clearly demonstrated the impossibility of depoliticizing national fiscal policy by relying on ever more constraining supranational rule-enforcement. With the Fiscal Compact still unchanged, alongside the stringent European Semester, Europeanized budgetary politics will continue to shape the contours of French democracy.

Open Access This article is distributed under the terms of the Creative Commons Attribution 4.0 International License (http://creativecommons.org/licenses/by/4.0/), which permits unrestricted use, distribution, and reproduction in any medium, provided you give appropriate credit to the original author(s) and the source, provide a link to the Creative Commons license, and indicate if changes were made.

\section{References}

Baldwin, R. et al. 2015. Rebooting the Eurozone: Step 1-agreeing a crisis narrative. http://voxeu.org/ article/ez-crisis-consensus-narrative. Accessed 26 Aug 2017.

Bale, T. 2015. Five year mission: The Labour Party under Ed Miliband. Oxford: Oxford University Press. Berry, C. 2016. Austerity politics and UK economic policy. Basingstoke: Palgrave Macmillan.

Bevir, M. 2000. New Labour: A study in ideology. The British Journal of Politics and International Relations 2(3): 277-301.

Bezes, P. 2006. Concurrences ministérielles et différenciation: la fabrique de la « réforme de l'État » en France dans les années 1990. In La Science Politique de l' administration, ed. F. Dreyfus and J.-M. Eymeri, 236-252. Paris: Economica.

Bezes, P., and P. Le Lidec. 2015. The French politics of retrenchment (2007-2012): Institutions and blame avoidance strategies. International Review of Administrative Sciences 81(3): 498-521.

Blyth, M. 2013. Austerity: The history of a dangerous idea. New York: Oxford University Press.

Bulmer, S., and W.E. Paterson. 2013. Germany as the EU's reluctant hegemon? Of economic strength and political constraints. Journal of European Public Policy 20(10): 1387-1405. 
Clift, B. 2006. The new political economy of dirigisme: French macroeconomic policy, unrepentant sinning, and the stability and growth pact. British Journal of Politics and International Relations 8(3): 388-409.

Clift, B. 2013. Le changement? French socialism, the 2012 presidential election and the politics of economic credibility amidst the eurozone crisis. Parliamentary Affairs 66(1): 106-123.

Clift, B., and M. Ryner. 2014. Joined at the hip, but pulling apart? Franco-German relations, the Eurozone crisis and the politics of austerity. French Politics 12(2): 136-163.

Cole, A. 2013. Politics as normal? The 2012 French presidential election. Parliamentary Affairs 66(1): 17-32.

Crouch, C. 2000. Coping with post-democracy. Fabian society pamphlet. http://www.fabians.org.uk/wpcontent/uploads/2012/07/Post-Democracy.pdf. Accessed 26 Aug 2017.

Crouch, C. 2011. The strange non-death of neo-liberalism. Cambridge: Polity.

Crouch, C. 2016. The march towards post-democracy, ten years on. Political Quarterly 87: 71-75.

Council of the European Union. 2013. www.consilium.europa.eu/uedocs/cms_data/docs/pressdata/en/ ecofin/140041.pdf. Accessed 26 Aug 2017.

Council of the European Union. 2015. Assessment of action taken by France in response to the council recommendation of 10 March 2015 with a view to bringing an end to the situation of excessive government deficit. http://eur-lex.europa.eu/legal-content/EN/TXT/HTML/?uri=CELEX: 52015DC0326\&from=EN. Accessed 26 Aug 2017.

Darvas, Z. and A. Leandro. 2015. The limitations of policy coordination in the euro area under the European semester. Bruegel Policy Contribution, issue no 19. http://bruegel.org/wp-content/ uploads/2015/11/pc_2015_194.pdf. Accessed 26 Aug 2017.

Dimitrakopoulos, D. (ed.). 2010. Social democracy and European integration: The politics of preference formation. Abingdon: Routledge.

Dunlop, C.A., and C.M. Radaelli. 2016. Policy learning in the Eurozone crisis: Modes, power and functionality. Policy Sciences 49(2): 107-124.

European Commission. 2013. Spring forecast. http://ec.europa.eu/economy_finance/publications/ european_economy/2013/pdf/ee2_en.pdf. Accessed 26 Aug 2017.

European Commission. 2015a. Communication from the commission to the European parliament, the council, the european central bank, the economic and social committee of the regions and the European investment bank making the best use of the flexibility within the existing rules of the stability and growth pact. http://eur-lex.europa.eu/legal-content/EN/TXT/HTML/?uri=CELEX: 52015DC0012\&from=EN. Accessed 26 Aug 2017.

European Commission. 2015b. http://ec.europa.eu/economy_finance/economic_governance/sgp/pdf/30_ edps/126-07_commission/2015-02-27_fr_126-7_commission_en.pdf. Accessed 26 Aug 2017.

Evans, J. and G. Ivaldi. 2017. Forces et faiblesses du Front National. Revue Politique et Parlementaire $1083 / 1084$

French Government. 2013. https://www.tresor.economie.gouv.fr/File/387830. Accessed 26 Aug 2017.

Gaffney, J. 2015. France in the Hollande presidency: The unhappy republic. Basingstoke: Palgrave.

Glencross, A. 2014. The eurozone crisis as a challenge to democracy and integration in Europe. Orbis 58(1): 55-68.

Gougou, F., and S. Persico. 2017. A new party system in the making? The 2017 French presidential election. French Politics 15(3): 303-321.

Guardian. 2012. Germany to set the terms for saving the euro. Guardian 31 January. https://www. theguardian.com/business/2012/jan/30/eu-summit-eurozone-treaty-deal. Accessed 26 Aug 2017.

Hall, P.A. 2012. The economics and politics of the euro crisis. German Politics 21(4): 355-371.

Heath, O. 2015. Policy representation, social representation and class voting in Britain. British Journal of Political Science 45(1): 173-193.

Heipertz, M., and A. Verdun. 2010. Ruling Europe: The politics of the stability and growth pact. Cambridge: Cambridge University Press.

Howarth, David. 2007. Making and breaking the rules: French policy on EU "gouvernement économique" and the stability and growth pact. Journal of European Public Policy 14(7): 1061-1078.

Kelemen, R.D., and T.K. Teo. 2014. Law, focal points, and fiscal discipline in the United States and the European Union. American Political Science Review 108(2): 355-370.

Kuhn, R. 2014. Mister unpopular: François Hollande and the exercise of presidential leadership, $2012-14$. Modern and Contemporary France 22(4): 435-457. 
Le Point. 2013. A quoi va ressembler la pause fiscale de Hollande? Le Point 6 September. http://www. lepoint.fr/economie/a-quoi-va-ressembler-la-pause-fiscale-de-hollande-05-09-2013-1721520_28. php. Accessed 26 Aug 2017.

Mair, P. 2013. Ruling the void: The hollowing-out of Western democracy. London: Verso.

Majone, G. 2001. Two logics of delegation: Agency and fiduciary relations in EU governance. European Union Politics 2(1): 103-122.

Marsh, D. 2009. The euro: The politics of the new global economy. New Haven/London: Yale University Press.

Mouffe, C. 2005. On the political (thinking in action). Abingdon: Routledge.

Puetter, U. 2012. Europe's deliberative Intergovernmentalism: The role of the council and European council in EU economic governance. Journal of European Public Policy 19(2): 161-178.

Ramiro, L. 2016. Support for radical left parties in Western Europe: Social background, ideology and political orientations. European Political Science Review 8(1): 1-23.

Richards, D., and M.J. Smith. 2015. In defence of British politics against the British political tradition. The Political Quarterly 86(1): 41-51.

Scharpf, F. 2010. The asymmetry of European integration, or why the EU cannot be a "social market economy". Socio-Economic Review 8(2): 211-250.

Schild, J. 2013. Leadership in hard times: Germany, France, and the management of the Eurozone crisis. German Politics and Society 31(1): 24-47.

Schimmelfennig, F. 2014. European integration in the euro crisis: The limits of postfunctionalism. Journal of European Integration 36(3): 321-337.

Schmidt, V. 2015. Forgotten democratic legitimacy: 'Governing by the rules' and 'ruling by the numbers'. In The future of the euro, ed. M. Blyth and M. Mathijs, 90-116. Oxford: Oxford University Press.

Varoufakis, Y. 2017. Adults in the room: My battle with Europe's deep establishment. London: Bodley Head.

White, J. 2015. Emergency Europe. Political Studies 63(2): 300-318.

Woodruff, D.M. 2016. Governing by panic: The politics of the Eurozone crisis. Politics and Society 44(1): 81-116. 